\title{
Ambrozjańska krytyka astrologicznej koncepcji fatum Juliusza Firmicjusza Maternusa Analiza Quaestio CXV
}

Teksty Starego i Nowego Testamentu wiążą astrologię z praktykami innych ludów. Ostatnim takim tekstem jest Pokłon Magów (Mt 2, 1-12)². Dzieje Kościoła stanowią proces proklamacji zbawienia w Chrystusie, dlatego praktyki astrologiczne są rugowane jako sprzeciwiające się prawdzie wiary ${ }^{3}$. Wiek II i III przynoszą krytykę chrześcijaństwa ze strony pogan. Cudowne wydarzenia inspirowane przez magów: Apoloniusza z Tyany, Aleksandra Abnouteichosa i Szymona Maga miały deprecjonować wartość czynów Chrystusa ${ }^{4}$. Teksty ojców Kościoła, apokryfy są

1 Ks. dr Grzegorz Babiarz, prefekt Wyższego Seminarium Duchownego Archidiecezji Krakowskiej. Specjalizacja z teologii dogmatycznej w zakresie patrologii.

2 Por. R. Pindel, Magia czy Ewangelia?, Kraków 2003, s. 195-206.

3 Por. R. Pindel, Magia czy Ewangelia?, dz. cyt., s. 322; M. Cholewa, M. Gilski, Rola myślenia w religijnej i magicznej interpretacji rzeczywistości, „Analecta Cracoviensia” 43 (2011), s. 8-10.

4 Por. D. Ogden, Magic, witchcraft, and ghost in the Greek and Roman worlds, Oxford 2009, s. $61-77$. 
świadectwem napięcia pomiędzy chrześcijaństwem a magią ${ }^{5}$. Wyraźne dane o praktykach astrologiczno-magicznych wśród chrześcijan są poświadczane przez papirusy magiczne oraz wypowiedzi synodów w Elwirze (306) oraz w Ancyrze (314) 6 .

IV wiek jest świadkiem wzmożonej walki pomiędzy chrześcijaństwem a magią. Angażuje się w nią także władza świecka. Po edykcie mediolańskim kolejne rozporządzenia cesarzy, od roku 356 do Kodeksu Teodozjusza (438), stopniowo ograniczają możliwość uprawiania magii . Warto przyglądnąć się temu zmaganiu chrześcijaństwa i magii w IV wieku. Problem jest ważny, ponieważ dotyka samych fundamentów chrześcijaństwa. Jak podkreślają ojcowie Kościoła, chrześcijaństwo i astrologia wykluczają się nawzajem. Uleganie fatum ma daleko idące konsekwencje dla życia religijnego ${ }^{8}$.

Celem publikacji jest przedstawienie jednej z najciekawszych polemik IV wieku - krytyki astrologicznej koncepcji fatum Juliusza Firmicjusza Maternusa zawartej w dziele Ambrozjastra zatytułowanym Quaestio CXV. Po zaprezentowaniu sylwetek życia i dorobku pisarskiego obu autorów w czterech punktach zostanie ukazana krytyka astrologii i fatum. Ambrozjaster przedstawia ich destrukcyjny wpływ na cztery sfery chrześcijańskiego życia: wiarę, kult, racjonalność myślenia oraz moralność.

Por. Orygenes, Przeciw Celsusowi, tłum. S. Kalinkowski, Warszawa 1986, I, 68.

6 Por. K. Preisendanz, Papyri Graecae Magicae. Die griechischen Zauberpapyri, MünchenLeipzig 2001, s. 209-323; autor przedstawia 35 papirusów, z czego 7 datuje się na 4 wiek: P 21 ok. roku 300, P 14: 3/4 wiek, P16: 4 wiek, P3: 4-5 wiek, P5a: 4 wiek, P13: 4-5 wiek, P19: 4-5 wiek. Por. M. Gilski, Chrześcijańskie papirusy magiczne, „Polonia Sacra” 27 (2010), s. 91-94; Acta Synodalia, red. A. Baron i H. Pietras, t. 1, Kraków 2006, s. 51.

7 Por. P. Wygralak, Stanowisko Kościoła wobec idolatrii i magii na terenach Galii i Hiszpanii w późnej starożytności chrześcijańskiej, Poznań 2011, s. 164-165; D. Collins, Magic in the ancient Greek world, Blackwell 2008, s. 162-165.

8 Por. M. L. W. Laistner, The western Church and astrology during the early middle ages, „Harvard Theological Review” 34 (1941), s. 252. 


\section{Tło historyczne sporu}

Działalność pisarska Juliusza Firmicjusza Maternusa i Ambrozjastra przypadają na IV wiek, przełomowy okres w historii chrześcijaństwa pod względem kształtowania się prawa kościelnego i państwowego krytykującego proceder magii i astrologii. Maternus pochodził z Sycylii, najprawdopodobniej z Syrakuz, gdzie spędził większość swego życia. W celu zdobycia wykształcenia wyjechał do Rzymu. Przebywając tam w latach 328-334, zaczął pisać dzieło poświęcone astrologii Matheseos, Libri VIII ${ }^{9}$. Ukończył je po trzech latach. Następnie ok. roku 343 nawraca się na chrześcijaństwo. Przypisuje się mu także autorstwo De errore profanarum religionum $(343-350)^{10}$.

Dzieło Matheseos stanowi jedyne ocalałe źródło łacińskiej terminologii astrologicznej oraz zawiera wycinkową wizję kultury wieku IV będącej pod wpływem religii orientalnych ${ }^{11}$. Zawiera odkrycia wiedzy astronomicznej Ptolemeusza, a pod względem ideowym zostaje głęboko poddane myśli stoickiej - dominującej roli fatum jako nieuchronnego zdeterminowanego porządku ${ }^{12}$. Pierwsza informacja na temat Maternusa - astrologa pojawia się na przełomie XI i XII wieku w odpisach dzieła Pseudo-Boecjusza De diis et praesensionibus, odnalezionych we Francji i Anglii ${ }^{13}$. De Matheseos szybko zyskuje dużą popularnośćc ${ }^{14}$.

$9 \quad$ Iulii Firmici Materni, Matheseos Libri VIII, Lipsiae 1913.

10 Iulii Firmici Materni, De errore profanarum religionum, Lipsiae 1907.

11 Por. Handbuch der latinischen Literatur der Antike, dz. cyt., s. 86; L. Thorndice, A Roman astrologer as a historical source: Julius Firmicus Maternus, „Classical Philology” 8 (1913), s. 415435; A. Busine, De Porphyre à Franz Cumont: La costruction des „religions orientales” de Firmicus Maternus, [w:] Référence Les 'religions orientales' dans le monde grec et romain: cent ans après Cumont (1906-2006), éd. V. Pirenne-Delforge, C. Bonnet, Roma 2009, s. 413-426.

12 Por. R. Y. Bram, Introduction, [w:] Ancient astrology theory and practice, Matheseos libri VIII by Firmicius Maternos, New Jersey 1975, s. 4.

13 Por. Handbuch der latinischen Literatur der Antike, dz. cyt., s. 88; W. Kroll, F. Skutych, K. Zielgler, Praefacio, [w:] Iulii Firmici Materni, Mathesseos Libri VIII, Lipsiae 1913, s. III; K. Zielgler, Firmicus Maternus, [w:] Reallexikon für Antike und Christentum, t. 7, Stuttgart 1969, s. 946-959.

14 Por. W. Kroll, F. Skutych, K. Zielgler, Praefacio, dz. cyt., s. III-XXXIII; W. Gundel, Astrologie, [w:] Reallexikon für Antike und Christentum, t. 1, Stuttgart 1950, s. 817-831. 
Ambrozjaster zainaugurował swoją działalność ok. 366 roku. W trakcie badań nad jego twórczością łatwiejsza była identyfikacja jego spuścizny literackiej (jedność teologiczno-filologiczno-redakcyjna) niż osoby ${ }^{15}$. Do podstawowych jego dzieł należą Ambrosiastri qui dicitur commentarius in epistulas Paulinas ${ }^{16}$ oraz Quaestiones ${ }^{17}$. Istnieje powszechna zgodność, że wspomniane rozprawy powstały do roku 384 (być może 386). Ostatnia z wymienionych dotarła do nas w kilku odpisach, niemniej jednak na podstawie jedności filologiczno-teologicznej istnieją mocne dowody, aby traktować je jako całość - 127 kwestii ${ }^{18}$. Każda kwestia stanowi odmienny traktat teologiczny. Quaestio $C X V^{19}$ powstała w Rzymie i była skierowana do katechumenów w postaci apologetycznego wykładu ${ }^{20}$. Wykazuje pewne podobieństwa $z$ dziełami polemicznymi Tertuliana ${ }^{21}$ : pewne elementy demonologii oraz odwołania do Ireneusza z Lyonu, Filona Aleksandryjskiego Anaksagorasa, Diogenesa Laertiosa ${ }^{22}$. Nie jest możliwe jednoznaczne związanie naszego autora $\mathrm{z}$ jednym środowiskiem ${ }^{23}$.

15 Informacje na temat identyfikacji Ambrozjastra oraz systematyczny przegląd literatury znajduje się w następującym opracowaniu: G. Babiarz, Grzech i nawrócenie w życiu ochrzczonych. Studium Komentarza Ambrozjastra do Listów św. Pawła, Kraków 2007, s. 25-35. Ostatnie publikacje przytaczają wyniki wcześniejszych badań. Por. S. Lunn-Rockliffe, Ambrosiaster's political theology, Oxford 2007, s. 12-62.

16 Ambrosiaster, Ambrosiastri qui dicitur commentarius in epistulas Paulinas in epistulam ad Romanos, ed. H. I. Vogels, Wien 1966 (Corpus Scriptorum Ecclesiasticorum Latinorum [dalej: CSEL], vol. 81, pars I); Ambrosiaster, Ambrosiastri qui dicitur commentarius in epistulas Paulinas in epistulas ad Corinthios, ed. H. I. Vogels, Wien 1968 (CSEL, v. 81, pars II); Ambrosiaster, Ambrosiastri qui dicitur commentarius in epistulas Paulinas in epistulas ad Galatos, ad Efesios, ad Filippenses, ad Colosenses, ad Thesalonicenses, ad Timotheum, ad Titum, ad Filemonem, ed. H. I. Vogels, Wien 1969 (CSEL, v. 81, pars III).

17 Ambrosiaster, Quaestiones Veteris et Novi Testamenti CXXVII, ed. A Souter, Wien 1960 (CSEL, v. 50).

18 Por. A. Berardino, Patrologia, Roma 1979, s. 169-180.

19 Ambrosiaster, Quaestio CXL, [w:] Quaestiones Veteris et Novi Testamenti CXXVII, dz. cyt., s. 318-349 [dalej: Quaestio 115, przypisy będą lokowane zgodnie z numeracją wprowadzoną przez redaktora tekstu łacińskiego].

20 Por. M. P. Bussières, Introduction, [w:] Ambrosiaster, Contre les païens (Question sur l'Ancien et le Nouveau Testament 114) et Sur le destin (Question sur l'Ancien et le Nouveau Testament 115), Paris 2007, s. 71.

21 Por. M. P. Bussières, Les quaestiones 114 et 115 de l'Ambrosiaster ont-elles été influences par l'apologétique de Tertullian?, „Revue des Études Augustiniennes” 48 (2002), s. 108-110.

22 Por. M. P. Bussières, Les quaestiones 114 et 115 de l'Ambrosiaster..., dz. cyt., s. 112-113.

23 Por. M. P. Bussières, Les quaestiones 114 et 115 de l'Ambrosiaster..., dz. cyt., s. 128. 
Ambrozjaster przyjął definicję fatum obecną w dziele Maternusa: są to działania powodowane przez astrologów usiłujących w oparciu o znajomość położenia ciał niebieskich odczytać powszechne przeznaczenie świata oraz wynikający z niego deterministycznie określony sposób postępownia człowieka. Wiedza ta ma charakter tajemny i niezmienny ${ }^{24}$. Nasz autor konstruuje swoją krytykę w następujący sposób: najpierw przytacza poglądy zwolenników astrologii, a następnie w oparciu o wykład wiary wykazuje nielogiczność fatum ${ }^{25}$.

\section{Fatum - niebezpieczeństwo utraty wiary}

Istnieje fundamentalna sprzeczność pomiędzy chrześcijaństwem a astrologią. Jest to nie tylko sprzeczność (contrarium), ale i wrogość (inimica):

Nihil tam contrarium Christiano, quam si arti matheseos adhibeat curam. Heac enim inimica dinoscitur dei legi ${ }^{26}$.

Nic nie jest bardziej przeciwne chrześcijaninowi, niż oddawanie się sztuce matheseosa [astrologii]. Uważa się bowiem, że jest ona nieprzyjazna Prawu Bożemu.

Nie ma punktów wspólnych pomiędzy fatum a Bogiem. Karze On nie tylko to, co czynią poddani astrologii, lecz potępia samo fatum ${ }^{27}$. Ambrozjaster pragnie ocalić chrześcijan przed jego negatywnymi skutkami, ponieważ posługuje się nim diabeł dla zakwestionowania czci należnej Bogu oraz szkodzenia ludziom. Autor Quaestio dostrzega daleko idące konsekwencje astrologii dla życia chrześcijańskiego: zarówno w samym akcie niewiary, relacji do Boga jako Stwórcy oraz podejścia do Prawa, rozumieniu sądu ostatecznego i oceny wartości ludzkiej natury.

Przyjęcie postawy związanej z fatum jest równoznaczne z odrzuceniem w sposób całościowy i jednoznaczny objawionego prawa Bożego. Stano-

24 Por. R. Y. Bram, Introduction, dz. cyt., s. 2; M. P. Bussières, Introduction, dz. cyt., s. 62.

25 Por. M. P. Bussières, Les quaestiones 114 et 115 del'Ambrosiaster..., dz. cyt., s. 127; M. P. Bussières, Introduction, dz. cyt., s. 81.

26 Quaestio 115, 1.

27 Quaestio 115, 65: „fata ex deo dici esse non poterunt, quia ista deus punit per legem. quando enim damnatur quod fit inpellentibus fatis, sine dubie fata damnatur". 
wi ono nową jakość, której nie można wyprowadzić z żadnej rzeczywistości dostępnej naturalnemu poznaniu ${ }^{28}$. Stąd jego przyjęcie jest wolnym wyborem $^{29}$. Astrologia w oparciu o determinizm kwestionuje możliwość niezależnych decyzji człowieka, dlatego w konsekwencji niesprawiedliwie ocenia postępowanie Boga i prowadzi do niewiary ${ }^{30}$.

Działanie Stwórcy jest racjonalne, ponieważ opiera się na poznaniu człowieka. Prawo pojawia się jako zbiór zasad, których przestrzeganie zapewnia właściwe odniesienia do Boga. Jest ono również punktem odniesienia dla przyszłego sądu, ponieważ jest możliwe do wypełnienia ${ }^{31}$. Dzięki prawu wola zdolna jest w oparciu o jego penitencjarny charakter z pełną świadomością dokonywać właściwego wyboru ${ }^{32}$. Przyjęcie fatum oznacza uznanie Boga za niesprawiedliwego prawodawcę ${ }^{33}$. Astrologia jest opowiedzeniem się po stronie diabła. Utwierdzony w swoim buncie, sprzeciwia się Bogu przez odrzucenie autorytetu i brak posłuszeństwa. Szuka najdogodniejszych sposobów osiągnięcia celu, kierując się przebiegłością, ukrywa swoje zamiary. Według autora Quaestio astrologia służy doprowadzeniu człowieka do drugiej śmierci.

${ }_{28}$ Quaestio 115, 80: ,hic enim fidei meritum est, quae non potest dici ex fato; quia quod creditur aliis saeculis auditum non fuit".

29 Por. Quaestio 115, 54.

30 Por. E. Staniek, Usprawiedliwiający charakter chrześcijańskiej wiary. Studium nad Komentarzami Ambrozjastra i Pelagiusza, Kraków 1982 (maszynopis rozprawy habilitacyjnej), s. 39-42.

31 Quaestio 115, 2: ,recte et salutami ratione legem dedit, scius posse hominem continere se ad id prohibet lex. igitur uia iuste legem dedit, non est utique inicus, cum vindicate".

32 Quaestio 115, 8: „quodsi iure remerandus est iustus et condemnandus iniustus, iam non naturae respondetur, sed voluntati, quia natura liberata est".

33 Quaestio 115, 3: , ars mathesos evitanda et fugienda est. Hanc enim astudia et subtilitas inventi diaboli. Quia enim aperte repugnare non audit auctori, tergiversatione id agit, ut et deo iniuriam faciat et hominem legi inimicum constituens morte multet secunda". Zgodnie z powszechnym przekonaniem demony były duszami zmarłych, których pomoc chciano pozyskać. Z samej struktury religijno-ezoterycznej stanowiły ambiwalentną część świata, bliską człowiekowi (paraedroi), którą można było zjednać dla realizacji zamiarów. Ambrozjaster wyraźnie przeciwstawia się takiemu pojmowaniu demonów i jednoznacznie określa ich jako przeciwników Boga i człowieka walczących w sposób zorganizowany. Por. A. Wypustek, Magia antyczna, Wrocław-Kraków-Warszawa 2001, s. 313-321; F. Graf, Magic in the ancient world, Cambridge 1997, s. 181; S. Lunn-Rockliffe, Ambrosiaster's political theology, dz. cyt., s. 149-152; G. Babiarz, Grzech i nawrócenie..., dz. cyt., s. 81-86. 
Fatum podważa sprawiedliwość Boga w dziele stworzenia, deprecjonując pojęcie i znaczenie natury ludzkiej ${ }^{34}$.Zgodnie z tezą Maternusa narodziny są podstawą do wydania generalnej oceny ludzkiego życia przez określenie ludzkiej natury jako złej lub dobrej. Takie podejście kłóci się z zasadą sprawiedliwości ${ }^{35}$. W konsekwencji odpowiedzialność za niegodziwe postępowanie człowieka i zło spada na Boga ${ }^{36}$. Astrologia wyklucza nie tylko równość ludzi wypływającą z natury, ale i wolność.

Według Ambrozjastra wiara funduje jedyną właściwą relację człowieka do Boga. Jej zaprzeczenie stanowi fatum, które propaguje fałszywy obraz Stwórcy, podważa jego sprawiedliwość i kwestionuje wartość człowieka oraz jego natury.

\section{Fatum - zagrożenie fałszywym kultem}

Świat przyrody podporządkowany jest prawu. Świadczy o tym wewnętrzny porządek. W konsekwencji kosmos jest zależny od Boga i ku niemu skierowany. Człowiek, pojawiając się w określonym punkcie historii, uczestniczy w tym procesie, którego widocznym znakiem ma być właściwy kult. Astrologia odrzuca wiarę, źródło prawdziwego kultu ${ }^{37}$. Tym samym prowadzi do idolatrii, negując teleologiczny wymiar stworzenia, zaprzecza możliwości interwencji Stwórcy oraz podważa sens modlitwy.

Astrologia jest zbytecznym sposobem opisu świata, służącym legitymizacji działania demonów ${ }^{38}$. Według naszego autora demony są po-

34 Por. Quaestio 115, 5.

35 Por. Quaestio 115, 6: „quod inistum utique videretur, si iste, quie naturae suae rem gesserat, igne ultore poenas pateretur aut alius adaeque naturae suae rem exequens preamiis adficeretur".

36 "Auctorem tangit vituperatio".

37 Quaestio 115, 42: „Hic est error mathematicorum, quo etiam deum pulsant. per hanc enim adseversationem negant aliquid posse fieri extra ordinem mundi, ut omnia, quae in mundo a deo facta leguntur, si a mundi lege discordat, negant credenda”.

38 Quaestio 115, 48: „Et antea vita hominum agrestis erat nec divttis studebatur: quo modo nunc astrologi per astra dicunt divites et pauperes fieri? Numquid mutata sunt astra, aut versutia et prestigium est satanae, ut ea per stellas dicat fieri, quae angelis suis ministris operatur?". 
gańskimi bożkami, które pragną podporządkować sobie ludzką wolność ${ }^{39}$. Najbardziej spektakularnym wyrazem zawłaszczenia wolności jest idolatria ${ }^{40}$. Ambrozjaster zwraca uwagę na niekonsekwencję astrologów. Z jednej strony podkreślają niezmienność fatum oraz bezowocność próśb zanoszonych do Boga ${ }^{41}$. Swoje zdanie opierają na rozumieniu świata przyrody jako podporządkowanego deterministycznym prawom, egzekwowanym i wyznaczonym przez regularność i niezmienność ruchu planet ${ }^{42}$. Z drugiej zaś pochwalają obrzędy wypraszania korzystnej wróżby ${ }^{43}$.

Pogarda wobec prawa uniemożliwia dostęp do prawdy na temat stworzenia oraz zamysłu Stwórcy. Astrolodzy pozbawieni właściwej wiedzy przywołują zjawisko cudu jako dowód niekonsekwencji postępowania Boga, który ustanawia prawa i jednocześnie je narusza. Ambrozjaster w odpowiedzi przywołuje dwie zasady: ducha prawa i hierarchii. Zgodnie z pierwszą prawo służy pomnażaniu życia, to zaś jest zgodne z naturą Boga - ingerując, ukazuje siebie i wypełnia zamysł prawa. Druga odwołuje się do pewności i jakości poznania - działanie Boga lepiej służy rozumieniu rzeczywistości ${ }^{44}$. Zaangażowanie Stwórcy przez ingerencję w historię jest jednym ze znaków Jego realności.

Bóg ma ciągle aktualną możliwość wprowadzania nowych faktów do świata przyrody, dlatego logika praw przyrody i stałej obecności Stwór-

39 Por. Quaestio 115, 31; M. P. Bussières, Les quaestiones 114 et 115 de l'Ambrosiaster..., dz. cyt., s. 116.

40 Por. K. Tyburowski, Przedmiot grzechu Adama w myśli Ambrozjastra na tle współczesnego mu status questionis, „Studia Sandomiersis” 10 (2003), s. 239-251.

41 Por. Quaestio 115, 77.

42 Quaestio 115, 41: „Haec mathematicorum adversatio est, ut dicant fata unmutari non posse neque precibus aliquid impetrari, quia semel deum dicunt statuisse totius mundi rationem et ministris deibus tradidisse, quae neque retro neque ante ferri possunt".

43 Por. Quaestio 115, 49; 115, 63. Jest to zapewne nawiązanie do starożytnych kolegiów augurów i haruspeksów, do których wróżb odwoływano się często. Por. G. Wissowa, Religion und Kultus der Römer, [w:] Handbuch der klassischen Altertums-Wissenschaft, München 1912, s. 523-549.

44 Quaestio 115, 43: „Sed trangressus videtur, aiunt, rationem quam statuit, ut aliter ipse fecisse dicatur, quam mundo decrevit. Age vero, mundo legem statuit faciendi aut generi: numquid sibi? [...] ut autem intellegentur a deo factum, non a mundo, alio ordine factum est". Por. także: Quaestio 115, 55; 115, 56. 
cy nie pozostają w sprzeczności ${ }^{45}$. Bóg jako suwerenny władca jest przeciwnikiem fatum. Nawet nieuchronność śmierci nosząca znamiona przeznaczenia nie wiąże z nim Stwórcy. Bóg zawsze objawia się jako Pan życia, o czym przekonuje historia Ezechiasza, w której opisano zaburzenie niezmiennego ruch planet ${ }^{46}$.

Uznanie fatum czyni daremnym wysiłki zrealizowania przemyślanego zamiaru oraz kwestionuje sens pobożności ${ }^{47}$. Autor Quaestio nazywa głupotą (stultitia) podejście astrologów do modlitwy. Za niedorzeczność uważa propagowanie działań określanych mianem nieskutecznych - nie można przecież akceptować publicznych aktów magicznych i jednocześnie być pewnym ich bezowocności. Po drugie niewłaściwym jest propagowanie zachowań pozbawionych jasnych zasad: trudno wskazać możliwość wpływu ludzkich oczekiwanń na nieuchronność zjawisk ${ }^{48}$.

Astrologia stanowi poważne zagrożenie dla prawdziwego kultu. odrzucając możliwość wiary w Boga, generuje przestrzeń dla zachowań absurdalnych, do jakich należy bałwochwalstwo, integralnie związane z czcią składaną demonom. Zaburzenie życia religijnego $\mathrm{u}$ jego podstaw prowadzi do fałszywego obrazu Boga jako obcego i niezdolnego zagwarantować bezpieczeństwa stworzeniu oraz pozostającego w izolacji od niego.

\section{Fatum - zaburzenie aktu poznawczego}

W naturze ludzkiej zakorzeniona jest wolnośćc ${ }^{49}$. Ocena postępowania pojawia się retrospektywnie w odniesieniu do pojedynczych działań, na-

45 Quaestio 115, 45: [imperator] nam ipsi soli licet revocare sententiam et reo mortis ignoscere: quanto magis deo licere debet [...] hoc enim deus sibi reservavit, unde apparet eum omnium esse dominum. Ad subruendum enim fatum pertinet".

46 Por. Quaestio 115, 46.

47 Por. Quaestio 115, 76.

48 Quaestio 115, 78: „stultum est fatum, quia supplicare facit hominem, quem scit non impetrare. quod si nescit an posit impetrare, quod illum facit supplicare, inprovidum erit fatum et carens ratione, quia omnis ignoratantia insipientia est, inscientia vero stultitia est”.

49 Por. Quaestio 115, 69. 
wet jeśli mają charakter sekwencyjny ${ }^{50}$. Obiektywny porządek świata ${ }^{51}$ oraz twórcze działanie ${ }^{52}$ pozwalają odkryć powszechność czynników związanych z przyrodniczym oraz prawno-społecznym opisem rzeczywistości. Człowiek ma możliwość dostępu do prawdy i przekraczania naturalnych odruchów. Astrologia nie ma zasad oraz precyzyjnych norm pozwalających na ocenę czynów. Błędnie rozumie tradycję oraz wychowawczą rolę środowiska społecznego.

Ambrozjaster opowiada się za obiektywną, immanentną normą moralną wykluczającą alternatywny sposób rozstrzygania o wartości działania. Przyjęcie fatum, uznanie sądu o człowieku w momencie narodzin fizycznych wprowadza obłęd (amentia) i niesprawiedliwość. Astrolodzy odrzucają tym samym sąd na końcu życia, utwierdzając w grzesznikach przekonanie o bezkarności. Sąd ostateczny dokona się w oparciu o prawo naturalne nakazujące czynić dobro i unikać zła. Jeśliby zostało ono zakwestionowane, ocena dokonywałaby się według subiektywnych spekulacji astrologów ${ }^{53}$. Prowadziłoby to do potrójnego błędu. Pierwszy: zakwestionowanie uznanego porządku rzeczy i pozytywnej wartości narodzin. Drugi: orzekanie o człowieku bez znajomości całego życia, brak wystarczających przesłanek. Ostatni: kwestionowanie wpływu złego postępowania na ocenę moralną człowieka ${ }^{54}$. Wewnętrzna niespójność fatum podważa jego wiarygodność ${ }^{5}$. Dodatkowo astrolodzy ignorują zewnętrzne czynniki mogące wpływać na zachowanie: lęk, seksualnośćs6, estety$\mathrm{kę}^{57}$. Mają one charakter niejednoznaczny. Na dowód tego Ambrozjaster

\footnotetext{
50 Por. Quaestio 115, 10; 115, 67; 115, 72.

51 Por. Quaestio 115, 21.

52 Por. Quaestio 115, 22; 115, 47; 115, 70.

53 Quaestio 115, 57: „Quo modo ergo quibusdam displicet futurum iudicium credere?
} Sed hoc mathematicorum invenit amentia. Quo modo enim possent futurum accipere iudicium, qui praesenti repugnant, quia iudicicum in nativitate esse contendunt? Et quia veritas, cum putatur premi, resurgit, ipsi, qui quodam iudico naturali bonos et malos non fieri, sed adserunt nasci, pecantibus retribuunt nec patiuntur inulta esse peccata".

54 Por. Quaestio 115, 58.

55 Quaestio 115, 61: „stare non potest quod per inconstantium rationis non tenet firmitatem".

56 Por. Quaestio 115, 19

57 Por. Quaestio 115, 20. 
przytacza przykład kastracji. Samookaleczenie było uważane przez Rzymian za niedopuszczalne i niegodne ${ }^{58}$. Natomiast w perskim kulcie Matris Magnae kastracja była elementem pobożności, dlatego mężczyźni poddawali się jej dobrowolnie ${ }^{59}$.

Zdolność autorefleksji oraz możliwość kształtowania działań dodają istotny element do natury i rodzą różnorodność osiągnięć kulturowych ${ }^{60}$ i personalnych ${ }^{61}$. Ciągłe wielowątkowe przekazywanie zachowań w ramach pokoleń może skutkować utwierdzeniem przekonania o istnieniu fatum $^{62}$. Ambrozjaster stoi jednak na stanowisku, że elementy kultury są owocem działań człowieka i jego zdolności do wielokrotnego powtarzania tych samych czynności ${ }^{63}$, co można obserwować w transporcie ${ }^{64}$ oraz przepisach kulinarnych ${ }^{65}$. Wytrwałość jest w stanie przeciwstawić się fatum, ponieważ jest ona jego wychowawcą ${ }^{66}$. To jej przysługuje pierwszeństwo w budowaniu działań - procedur służących osiągnięciu zamierzonego celu. Myślenie o fatum należy zastąpić przez działanie przemyślane, perspektywiczne, okupione wysiłkiem ${ }^{67}$.

Generowana przez fatum niepewność uniemożliwia znalezienie zasady funkcjonowania zjawisk. Zaburza ono relację przyczynowo-skutkową, ruguje czytelne normy. Usuwa z życia publicznego czynniki pobudzające do właściwego postępowania: ogólny porządek, akceptowany zwyczaj, przykład oraz karę odstraszającą niemających wystarczającego rozeznania niegodziwości ${ }^{68}$. Ambrozjaster wskazuje, że powyższe wytyczne stanowią aplikację zapowiedzianego sądu Boga, który przez lęk (metus) i zapowiedzianą karę (poena) mobilizuje ludzi do właściwego postępowa-

58 Por. Quaestio 115, 17.

59 Por. Quaestio 115, 18.

60 Por. Quaestio 115, 74.

61 Por. Quaestio 115, 75.

62 Por. Quaestio 115, 25.

63 Por. Quaestio 115, 26.

64 Por. Quaestio 115, 23.

65 Por. Quaestio 115, 24.

${ }_{66}$ Quaestio 115, 27: „disciplinae, quae etiam ipsius fati pedagogus est”.

67 Quaestio 115, 71: „quod enim excogitator et diu pensitatur et exercititiis mediis adquriritur, cur fati esse dicatur?".

68 Por. Quaestio 115, 59. 
nia. Próba zrównania fatum i Boga w organizowaniu rzeczywistości pozostaje utopią, ponieważ to, co domniemane i wewnętrznie sprzeczne, pozostaje tylko nieskuteczną tezą wobec realnego działania Stwórcy ${ }^{69}$.

Przyjęcie fatum pozbawia człowieka pewności oceny własnego działania. Kwestionowanie treści i hierarchii norm naraża na sięganie po doraźne normy i sztuczną ich absolutyzację. Dodatkowo ogranicza patrzenie na tradycję i normy społeczne jako na elementy wyłącznie opresywne.

\section{Fatum - zaburzenie norm moralnych}

Wyrugowanie wskazówek porządkujących ludzkie postępowanie stwarza okazję do konstruowania uzasadnień dla niegodziwości, rozbija jedność działania osoby. Dominacja zmysłów powoduje fałszywe oskarżanie innych, rodzi pragnienie uniknięcia cierpienia za wszelką cenę.

Fatum, ze względu na deprecjonowanie obiektywnych zasad, najchętniej jest przyjmowane przez lubiących odpoczynek, rezygnujących z wysiłku rozumowego. Wtedy zło może łatwo podsunąć pragnienie, które nie zostanie właściwie ocenione ${ }^{70}$. Ambrozjaster jednoznacznie podkreśla, że fatum jest wygodne dla pragnących żyć niemoralnie. Oddając się rozwiązłości i pożądliwości, tracą kontrolę nad własnym postępowaniem

69 Quaestio 115, 28: „et quid est, nescio, ut tantam inuidiam fato faciant, ut in omnibus gestis ipsum dicant auctorem, cum sit et non sit? Ubi enim disciplina est, non est et, ubi consuetudine est, non est et, ubi casus est, non est. Ubi autem videtur esse, timore legis vincitur; et libido enim metu conpescitur et quaestus pecunie propter deum promerendum repudiator. In hac ergo parte negari non potest, quia non potest non esse, quod vincitur, et tamen recte potest dici et in eo ipso non esse, quia caret auctoritate, quod vincitur".

70 Quaestio 115, 29: „nam male vivere volens ipsi sibi fata constituunt. Per luxoriam enim et voluptatem fit intemperantia et inquietudo, quae parit incontinentiam et iracundiam. Et scientes istud poena dignum, ut imunes se faciant, pudorem passi fatis hoc adscribunt, cum de hac re cogitantibus adiuturium faciant demones: qui ad hoc stant, ut male cogitantibus tribuant effectum, stios fata appellant non intellegentes, quia sunt hominis inimici”. Por. Quaestio 115, 4; G. Babiarz, Grzech i nawrócenie..., dz. cyt., s. 87-97. Istotną częścią uprawiania magii była sfera emocjonalna (erotyczna) człowieka. W ramach jej praktykowania starano się zdobyć przychylność bądź zabezpieczyć się przed uzależnieniem. Por. J. J. Winkler, The Constraints of Eros, [w:] Magika Hiera. Ancient Greek magic and religion, ed. Ch. A. Faraone, D. Obbink, Oxford 1991, s. 214-243. 
i doznają niepokoju. Skutkuje to nieuporządkowanymi, pełnymi gniewu relacjami z innymi. Wstępne rozeznanie tego stanu rzeczy nie skutkuje nawróceniem, lecz przeradza się w kolejną niegodziwość, rozbudowanie astrologii. Zdolności człowieka zostają wykorzystane dla uzasadnienia niegodziwości. Takie działanie zostaje wsparte działaniem demonów, zmierzających do większego uwikłania w zło i zrzucenia odpowiedzialności na czynniki zewnętrzne.

Według Ambrozjastra wewnętrzna logika zła prowadzi do zintensyfikowania niegodziwości. Istotną jej częścią jest oddziaływanie na zmysły. Przy ich pomocy zło wzbudza pożądanie, jak wydaje się grzesznikom, ma ono charakter nieopanowanego pragnienia. Towarzyszy temu doświadczenie przyjemności oraz wartości zamierzonego celu. Wspomniane przeżycia generują przekonanie o nieuchronności takiego odniesienia, co zgadza się z logiką fatum. Autor Quaestio podkreśla możliwość odrzucenia każdej okazji do grzechu ${ }^{71}$. Zło wzbudza niechęć do spraw Bożych, co sprzyja pojawieniu się wzburzenia przyczyniającego się do uruchomienia naturalnych odruchów ciała ${ }^{72}$. Należy jednak odróżnić od nich działanie szatana, który może wpłynąć na ludzkie ciało, osłabić sprawność działania - przykład córki Abrahama dotkniętej chorobą (por. Łk 13, 18) ${ }^{73}$.

Zaktualizowanie myślenia deterministycznego zawiesza odpowiedzialność za czyny. Oprawca kierujący się wyrocznią pozostaje niewinny, winną staje się ofiara ${ }^{74}$. Paradoksem fatum jest jego podejście do prawa. Z jednej strony postuluje jego odrzucenie, a z drugiej ze względu na destrukcyjne skutki domaga się nowych norm. Astrologia pozbawiona jest rozumności (ratio), ponieważ skutki pozostają sprzeczne z wyzna-

71 Quaestio 115, 30: „Nam si per sensus non subintrarent peccata ad animam, sed de intus nascerentur, recte omne, quod delinquitur, fatorum esse diceretur. at cum videant autem per visum ea auditum et per reliquos sensus nasci concupiscentiam peccatorum adiutantibus inimicis, qui suggerunt faciendum, quod contrarium est et non putatur, quamdiu fiat - dulce enim videtur, cum fit aut antequam fiat; perfectum autem apparet esse amarum-, quid fatis inputant?".

72 Por. Quaestio 115, 32.

73 Por. Quaestio 115, 33.

74 Por. Quaestio 115, 64. 
czonymi celami. Niegodziwość i nieracjonalność potwierdzają konieczność jej odrzucenia ${ }^{75}$.

Nieodzowne dla właściwej oceny fatum staje się dostrzeżenie perspektywy nagrody gwarantowanej słowem Boga. Wszyscy wierzący podejmują walkę, a świat jest areną zmagań. Owoce zwycięstwa mogą być widoczne w teraźniejszości lub wieczności. W wypadku wierzących częściej zdarza się, że przyznanie im sprawiedliwości jest raczej sprawą przyszłości. Wtedy sami ukażą się jako sprawiedliwi i będą mogli oskarżyć swoich oprawców. Ich wyrok zostanie promulgowany decyzją Boga. W czasie obecnego życia rzeczą niezmiernie ważną jest ograniczanie swoich pragnień i zachowanie postawy wdzięczności. Nawet jeśli wierzący otrzyma doczesną nagrodę, to nie traci jej w przyszłości, ponieważ opiera się ona na prawie dziedziczenia $^{76}$. Nadzieja chrześcijańska odnosi zwycięstwo nad fatum ${ }^{77}$.

Chrześcijaństwo konstruuje nowe pojęcie szczęścia. Jego miarą jest wolność od grzechu ${ }^{78}$. Do obrony przed działaniem zła i przyznaniem mu absolutnego statusu człowiek otrzymuje wsparcie ze strony Boga ${ }^{79}$. Są to zasady umożliwiające pewne poznanie i pozwalające odrzucić pokusy. Akceptowanie prawa przyczynia się do lepszego poznania Boga i uznania za wroga szatana, który jednocześnie zostaje rozpoznany jako wróg przykazań. Cielesność jako droga realizacji fatum zostaje pozbawiona swej mocy ${ }^{80}$.

75 Quaestio 115, 60: „Sed et hoc ipsum fati forte fuit, ut lex daretur. et qua ratione fata subsistent, si generant a quo destruantur. Quia quod fati est contra dixit lex fieri debere? Carent ergo ratine, si contraria sibi generant, et iniqua sunt, quai nasci faciunt hominess ad damnationem, et si iniqua sunt, auctoritatem habere non debent, quia omne iniquum ponitioni obnoxium est".

76 Por. Quaestio 115, 53.

77 Quaestio 115, 51: „Qua igitur spe Christiani mathematicis aures commodant, cum audient Iohannem apsostolum clamantem et dicentem: nolite diligere hunc mundum neque ea, quae in mundo sunt? itaque si haec sunt fidei vel legis nostrae praecepta, ne mundus diligatur neque ea, quae in mundo sunt".

78 Por. Quaestio 115, 52.

79 Quaestio 115, 35: ,ideo enim imperator est corporis animus, ut guberent eum retinaculis legis divinae. Ea enim, quae sive inpulsu carnis sive ab inimico suggerentur, non esse utilia lex ostendit divina, auam ideo adiuturio dedit deus, ut dictantem inimicum quasi bona respicientes legis praecepta intellegamus illum esse seductorem, quai aliud suadet quam docet lex". Por. także Quaestio 115, 79.

80 Por. Quaestio 115, 36. 
Według naszego autora fatum pozbawia człowieka jakiejkolwiek odpowiedzialności za kształt własnego życia i prowadzi do bezkrytycznego usprawiedliwiania złych działań oraz podporządkowania zmysłom.

\section{Zakończenie}

Ambrozjaster w swojej polemice z Juliuszem Firmicjuszem Maternusem wskazuje na cztery zagrożenia płynące $\mathrm{z}$ faktu przyjęcia fatum. Jest ono wyrazem niewiary i odrzucenia objawienia. Deprecjonuje bowiem intencje Stwórcy i przyczynia się do wykreowania Jego obrazu jako niesprawiedliwego i despotycznego.

Fałszywy obraz Boga prowadzi do fałszywego kultu. Wyznawcy astrologii kwestionują możliwość cudu oraz modlitwę, wskazując jako alternatywę quasi-religijnie zamkniętą doczesność.

Brak wiary i idolatria mają swoje konsekwencje w obszarze poznania oraz moralności. Istotną konsekwencją przyjęcia fatum jest destrukcja osoby w odniesieniu do jej możliwości poznawczych oraz postępowania według zasad moralnych.

Ambrozjaster udowadnia, że zna doskonale dzieło Firmicjusza. Poglądy w nim zawarte traktuje jako poważne zagrożenie dla chrześcijaństwa. Dodatkowo Quaestio CXV jest świadectwem coraz większej różnicy, jaka zachodziła między demonologią kulturową a przedstawianą przez wykład nauki objawionej.

Wykład naszego autora wpisuje się w szeroki kontekst społeczno-religijny IV wieku. Otwiera on także pole do dyskusji na temat wewnętrznej kondycji chrześcijaństwa okresu tolerancji oraz jego wpływu na kształtowanie się zachowań religijnych i społecznych. 


\section{Summary}

\section{Ambrosiaster's Critique of Julius Firmicus Maternus's Astrological Concept of Fate. Analysis of Quaestio CXV}

The polemic of Ambrosiaster against Julius Firmicus Maternus has been presented in five points. The first point is introduction. The second point describes fate in terms of an act of disbelief because it depreciates the Creator and contributes to portraying him as unjust and tyrannical. The third point presents a method of Astrology used to build a false worship: by rejecting the concept of miracle and prayer. Another point concerns the effects of rationality disorder induced by the logic of fate. The last point shows the destruction of the structure of a person trapped in irrationality.

Ambrosiaster proves that he knows the work of Firmicus perfectly. He treats it as a serious threat to Christianity. In addition, Quaestio $C X V$ is a testament to a growing disparity between cultural demonology and the one presented in the revealed teaching.

The teaching of this author constitutes a part of a wide socio-religious context of the 4th century. It also opens up the field for discussion about the internal condition of Christianity of the tolerance period and its impact on the development of religious and social behaviours.

Keywords: astrology, fate, rationality, worship

\section{Ambrozjastra krytyka astrologicznej koncepcji fatum Juliusza Firmicjusza Maternusa. Analiza Quaestio CXV}

Polemika Ambrozjastra z Juliuszem Firmicjuszem Maternusem została przedstawiona w pięciu punktach. Pierwszy jest wprowadzeniem w polemikę. Drugi opisuje fatum w kategoriach aktu niewiary, ponieważ deprecjonuje Stwórcę i przyczynia się do wykreowania jego obrazu jako niesprawiedliwego i despotycznego. Trzeci prezentuje metodę obecną $\mathrm{w}$ astrologii przy budowaniu fałszywego kultu: odrzucenie pojęcia cudu oraz modlitwy. Kolejny dotyczy skutków zaburzenia racjonalności powodowanych logiką fatum. Ostatni ukazuje destrukcję struktury osoby uwikłanej w nieracjonalność.

Słowa kluczowe: astrologia, fatum, kult, racjonalność

\section{Bibliografia}

Acta Synodalia, red. A. Baron i H. Pietras, t. 1, Kraków 2006.

Ambrosiaster, Ambrosiastri qui dicitur commentarius in epistulas Paulinas in epistulam ad Romanos, rec. H. I. Vogels, Vindobonae 1966 (Corpus Scriptorum Ecclesiasticorum Latinorum, v. 81, pars I). 
Ambrosiaster, Ambrosiastri qui dicitur commentarius in epistulas Paulinas in epistulas ad Corinthios, ed. H. I. Vogels, Vindobonae 1968 (Corpus Scriptorum Ecclesiasticorum Latinorum, v. 81, pars II).

Ambrosiaster, Ambrosiastri qui dicitur commentarius in epistulas Paulinas in epistulas ad Galatos, ad Efesios, ad Filippenses, ad Colosenses, ad Thesalonicenses, ad Timotheum, ad Titum, ad Filemonem, rec. H. I. Vogels, Vindobonae 1969 (Corpus Scriptorum Ecclesiasticorum Latinorum, v. 81, pars III).

Ambrosiaster, Quaestio CXV; [w:] Pseudo-Augustini Quaestiones Veteris et Novi Testamenti CXXVII, rec. A. Souter, Wien 1960, s. 318-349 (Corpus Scriptorum Ecclesiasticorum Latinorum, 50).

Babiarz G., Grzech i nawrócenie w życiu ochrzczonych. Studium Komentarza Ambrozjastra do Listów św. Pawła, Kraków 2007.

Berardino A., Patrologia, Roma 1979.

Bram R. Y., Introduction, [w:] Ancient astrology theory and practice, Matheseos libri VIII by Firmicius Maternos, New Jersey 1975, s. 1-10.

Busine A., De Porphyre à Franz Cumont: La costruction des ,religions orientales" de Firmicus Maternus, [w:] Référence Les 'religions orientales' dans le monde grec et romain: cent ans après Cumont (1906-2006), éds. V. Pirenne-Delforge, C. Bonnet, Roma 2009, s. 413-426.

Bussières M. P., Introduction, [w:] Ambrosiaster, Contre les païens (Question surl'Ancien et le Nouveau Testament 114) et Sur le destin (Question sur l'Ancien et le Nouveau Testament 115), Paris 2007, s. 39-105.

Bussières M. P., Les quaestiones 114 et 115 de l'Ambrosiaster ont-elles été influences par l'apologétique de Tertullian?, „Revue des Études Augustiniennes” 48 (2002), s. 103-130.

Cholewa M., Gilski M., Rola myślenia w religijnej i magicznej interpretacji rzeczywistości, „Analecta Cracoviensia” 43 (2011), s. 7-23.

Collins D., Magic in the ancient Greek world, Blackwell 2008.

Gilski M., Chrześcijańskie papirusy magiczne, „Polonia Sacra” 27 (2010), s. 89-97.

Graf F., Magic in the ancient world, Cambridge 1997.

Gundel W., Astrologie, [w:] Reallexikon für Antike und Christentum, t. 1, Stuttgart 1950 , s. 817-831.

Handbuch der latinischen Literatur der Antike, hg. von R. Herzog, P. L. Schmidt, t. 5: Die latinische Literatur von 284 bis 374 n. Chr., München 1989.

Iulii Firmici Materni, De errore profanarum religionum, Lipsiae 1907.

Iulii Firmici Materni, Mathesseos Libri VIII, Lipsiae 1913.

Kroll W., Skutych F., Zielgler K., Praefacio, [w:] Iulii Firmici Materni, Mathesseos Libri VIII, Lipsiae 1913, s. III-XXXVI, s. III.

Laistner M. L. W., The western Church and astrology during the early middle ages, „Harvard Theological Review" 34 (1941), s. 251-273.

Lunn-Rockliffe S., Ambrosiaster's political theology, Oxford 2007.

Ogden D., Magic, witchcraft, and ghost in the Greek and Roman worlds, Oxford 2009.

Orygenes, Przeciw Celsusowi, tłum. S. Kalinkowski, Warszawa 1986.

Pindel R., Magia czy Ewangelia?, Kraków 2003. 
Preisendanz K., Papyri Graecae Magicae. Die griechischen Zauberpapyri, MünchenLeipzig 2001.

Staniek E., Usprawiedliwiajacy charakter chrześcijańskiej wiary. Studium nad Komentarzami Ambrozjastra i Pelagiusza, Kraków 1982.

Thorndice L., A Roman astrologer as a historical source: Julius Firmicus Maternus, „Classical Philology" 8 (1913), s. 415-435.

Tyburowski K., Przedmiot grzechu Adama w myśli Ambrozjastra na tle współczesnego mu status questionis, „Studia Sandomiersis” 10 (2003), s. 239-251.

Winkler J. J., The constraints of Eros, [w:] Magika Hiera. Ancient Greek magic and religion, ed. Ch. A. Faraone, D. Obbink, Oxford 1991, s. 214-243.

Wissowa G., Religion und Kultus der Römer, [w:] Handbuch der klassischen Altertums-Wissenschaft; München 1912, s. 523-549.

Wygralak P., Stanowisko Kościoła wobec idolatrii i magii na terenach Galii i Hiszpanii w późnej starożytności chrześcijańskiej, Poznań 2011.

Wypustek A., Magia antyczna, Wrocław-Kraków-Warszawa 2001.

Zielgler K., Firmicus Maternus, [w:] Reallexikon für Antike und Christentum, t. 7, Stuttgart 1969, s. 946-959. 